\title{
Seroprevalance of Parvovirus B19 among Kidney Transplant in Libya
}

\author{
Musbah Almbsuot ${ }^{1}$ *, Bayram Kiran ${ }^{2}$, Elfatah Elnifro $^{3}$, Basm Rajab $^{1}$, \\ Altayeb Elazomi ${ }^{4}$, Fawzia Shawesh ${ }^{4}$ and Abd Alla A. Mohamed ${ }^{4}$ \\ ${ }^{1}$ kastamonu University Institute of science, kastamonu-Turkey \\ ${ }^{2}$ Istanbul University Faculty of medicine, Istanbul-Turkey \\ ${ }^{3}$ Department of Medical Microbiology, Medical School, University of Al-Marghib, \\ Al-Kums- Libya \\ ${ }^{4}$ Department of Medical Laboratories, Faculty of Medical Technology, \\ University of Zawia, Libya \\ *Corresponding author
}

\section{A B S T R A C T}

Parvovirus B19 is a single strand DNA virus belongs to the Parvoviridia family and only parvovirus known to be a pathogen in human. It is causing several problems in human

\section{Keywords}

Parvovirus B19, ELISA, Kidney transplant, Anemia, reticuloncytopenia

Article Info

Accepted:

10 March 2019

Available Online:

10 April 2019 especially in immunosuppressed patients such as organ transplant recipients. In kidney transplant patients parvovirus B19 can continue for years due to failure of the immune response and it may be associated with chronic clinical manifestations such as anemia and another reticuloncytopenia. Fifty renal transplant patient who checked up in two main kidney transplant centers in Libya. During the 2017 in different years post transplantation, the blood samples were collected support by questioner include some information about patient. All samples were analyzed by enzyme-linked immunosorbent assay technique (ELISA) for antibody detection of Parvovirus B19 IgM and parvovirus B19 IgG depended on indirect ELISA principles. The seropositive of Parvovirus B19 rate was $6 \%$ for IgM (acute infection) and $66 \%$ for IgG (chronic infection). Seropositive of ParvovirusB 19 in Libyan kidney transplant (Both IgM, IgG) depends on age; most age affected was between 20-39 years old. The conclusion demonstrated that ParvovirusB19 common among kidney transplant in Libya and 35\% of Libyan kidney transplant patients were susceptible to the infection by B19 (do not have antibodies).

\section{Introduction}

Parvovirus B19 is a single stranded DNA virus member of Parvoviridae family of viruses that consist of many types of animal parvoviruses such as the canine parvovirus and feline panleukopenia virus. Specific parvovirus B19 only infect human, the virus replicates in rapidly dividing erythroid progenitor cells. Other target cells are less well defined and may include myocardial tissue. Infection with parvovirus is very common and worldwide. The conquestion is often during childhood and continues at lower 
rates throughout adulthood between 70 and $85 \%$ of adults show serologic evidence of past infection. Infectivity shows seasonal variation in temperate climates, being more common in winter and spring. Transmission of infection usually occurs by inhalation of virus in aerosol droplets. Infection also can be transmitted vertically from mother to fetus and less commonly through transfusion of blood products bone marrow transplants, and organ transplants ${ }^{1}$.

In immunocompetent B19 is causes erythema infectiosum (fifth disease), in pregnant women it leads to hydrops fetalis. In immunosuppressed patients such as organ transplant recipients, B19 virus can continue for years due to failure the immune response and it may be associated with chronic clinical manifestations such as anemia and another cytopenia. B19 infection in transplanted patients B19 infection is transmitted through the donor organ or blood products, during transfusion. Increased susceptibility due to immunosuppressive therapy is likely establishment of infection B19 is not frequently regarded as a cause of anemia in immunosuppressed Patients, though anemia without previous blood loss or reticulocytopenia should alert for potential B19 infection. Red cell aplasia and severe anemia are also manifestations of B19 infection in organ transplant recipients and is directly related to the virus tropism for human erythroid precursor cells. Presence of virus in bone marrow leads to prolonged suppression of erythropoiesis in spit many cases of B19 infection in renal transplanted patients and various infection-related complications have been reported; only a few studies have been performed to evaluate the incidence of active B19 infection in anemic transplanted patients, reported incidences of this infection vary from 23 to $31.1 \%$ of the cases. In particular, KT recipients may acquire symptomatic parvovirus B19 infection from the donor, from the community, or from reactivation of endogenous latent or persistent ${ }^{2,3}$

\section{Materials and Methods}

Study was case series descriptive study done in in two main kidney transplant centers in Libya, Tripoli city (Tripoli Central Hospital), and Benghazi city (General Hawari Hospital) during the period from first of January 2017 to end of December 2017 in different years post transplantation. The kidney donors came from their families, the kidney recipients originated from different region of Libya. Fifty renal transplant patient (10 women and 40 men) age ranged between 12-64 years old were checked up and the blood samples were also taken to investigate for presence of $\mathrm{IgG}$, and IgM antibodies for Parvovirus B19. The samples undergo to analysis by ELISA, and CBC equipment to detect the seropositively of Parvovirus B19, and find relationship between anemia and parvovirus B19 infect.

All blood KT samples were collected in $5 \mathrm{ml}$ blank tube and lifted for 15 minutes to clot; then the tubes centrifuged for $5 \mathrm{~min}$ at 3000 RPM to separate the serum. The separated sera were transferred to other tubes; every tube given number corresponds to patient name on the questionnaire and kept frozen at 20 until transferred) till analyses. Human serum IgG and $\operatorname{IgM}$ antibodies to parvovirus B19 were detected by enzyme-linked immunosorbent assay (ELISA) (The Alegriaparvovirus B19 IgG (ORG-Germany), and The Alegria parvovirus B19 IgM kit(ORGGermany), all test data are transferred to the system through individual barcodes on the AlegriaTest Strip. Calculation and interpretation of results will be performed automatically. As mention before taking blood, some relevance data was taken by questionnaire for each subject this data was collected through direct interview by senior officer doctor working with kidney transplant 
department during the work of study, and blood was taken by phlebotomist and stored in kidney transplant center laboratory until analyzed.

Data analysis was performed with computer software (SPSS version 23) Frequencies, percentages were computed and the comparison was made by Chi Squire Analysis to examine significant relationship between different variables in the data. Statistical significance was taken at a $\boldsymbol{p}$ value of less than 0.05 .

\section{Results and Discussion}

In this study, 66\% kidney transplant recipients were positive to parvovirus B19 and 6\% were positive to parvovirus $\mathrm{B} 19$. The results showed a significant association between prevalence of $\operatorname{IgG}$ and age groups, $\chi^{2}(2, \mathrm{n}=$ $50)=5.236, p=0.022$ (Table 1), While there was no significant association between prevalence of $\operatorname{IgM}$ and age groups, $\chi 2(2, \mathrm{n}=$ $50)=1.106, p=0.240$ (Table 2). There was no significant between seropositivity of both $\mathrm{IgG}$ and IgM sex groups, respectively $\chi^{2}(1, \mathrm{n}=$ $50)=1.252, p=0.263, \chi 2(1, \mathrm{n}=50)=2.214$, $p=0.080$ (Table 3 and Table 4).

The results showed non-significant different with post transplantation period for $\mathrm{IgG}$ for B1 $\chi^{2}(1, \mathrm{n}=50)=.128, p=0.720$ (Table 5).

Non-significant different with post transplantation period to IgM for B19 $\chi^{2}(1, \mathrm{n}$ $=50)=0.345, p=0.542$. In case of IgM prevalence all of infection occur during of first five years after transplantation due to highly immunosuppressant (Table 6).

According to the level of hemoglobin, the study was showed no significant association of anemia and both $\operatorname{IgG}$, and $\operatorname{IgM}$ for B19 respectively $\chi^{2}(1, \mathrm{n}=18)=1.507, p=0.119$, $\chi^{2}(1, \mathrm{n}=18)=.000, p=1.000$ (Table 7 and $8)$.

Table.1 Prevalence of $\mathrm{IgG}$ according the age groups

\begin{tabular}{|c|c|c|c|c|c|}
\hline \multicolumn{2}{|c|}{} & \multicolumn{2}{|c|}{ Age } & \multirow{2}{*}{ Total } \\
\cline { 3 - 6 } \multicolumn{2}{c|}{} & $\begin{array}{c}\text { Less than 38 years } \\
\text { old }\end{array}$ & $\begin{array}{c}38 \text { years and } \\
\text { above }\end{array}$ & \\
\hline \multirow{2}{*}{ B19 IgG } & Negative & Count & $26 \%$ & $8 \%$ & $34 \%$ \\
\cline { 2 - 6 } & Positive & Count & $28 \%$ & $38 \%$ & $66 \%$ \\
\hline & total & count & $54 \%$ & $46 \%$ & $100 \%$ \\
\hline
\end{tabular}

Table.2 Prevalence of IgM according the age groups

\begin{tabular}{|c|c|c|c|c|c|}
\hline \multicolumn{2}{|c|}{} & \multicolumn{2}{c|}{ Age } & \multirow{2}{*}{ Total } \\
\cline { 3 - 5 } & & $\begin{array}{c}\text { Less than 38 years } \\
\text { old }\end{array}$ & 38 years and above & \\
\hline \multirow{2}{*}{ B19 } & Negative & Count & $48 \%$ & $46 \%$ & $94 \%$ \\
\hline \multirow{2}{*}{ IgM } & Positive & Count & $6 \%$ & $0 \%$ & $6 \%$ \\
\hline \multicolumn{2}{|c|}{ Total } & Count & $54 \%$ & $46 \%$ & $100 \%$ \\
\hline
\end{tabular}


Table.3 Prevalence of IgG according the sex groups

\begin{tabular}{|c|c|c|c|c|c|}
\hline \multicolumn{2}{|c|}{} & \multicolumn{2}{c|}{ Sex } & \multirow{2}{*}{ Total } \\
\cline { 3 - 6 } \multicolumn{2}{c|}{} & & Male & Female & \\
\hline \multirow{2}{*}{ B19 IgG } & Negative & Count & $24 \%$ & $10 \%$ & $34 \%$ \\
\hline & Positive & Count & $58 \%$ & $8 \%$ & $66 \%$ \\
\hline & Total & count & $82 \%$ & $18 \%$ & $100 \%$ \\
\hline
\end{tabular}

Table.4 Prevalence of IgM according the sex groups

\begin{tabular}{|c|c|c|c|c|c|}
\hline \multicolumn{2}{|c|}{} & \multicolumn{2}{c|}{ Sex } & \multirow{2}{*}{ Total } \\
\cline { 3 - 6 } & \multicolumn{2}{|c|}{} & Male & Female & \\
\hline B19 IgM & Negative & Count & $80 \%$ & $14 \%$ & $94 \%$ \\
\hline & Positive & Count & $2 \%$ & $4 \%$ & $6 \%$ \\
\hline & Total & count & $82 \%$ & $18 \%$ & $100 \%$ \\
\hline
\end{tabular}

Table.5 Seroprevalence of B19 IgG according the time post transplantation

\begin{tabular}{|c|c|c|c|c|c|}
\hline \multicolumn{2}{|c|}{} & & \multicolumn{2}{c|}{ Time passed since plantation } & Total \\
\hline \multicolumn{2}{|c|}{} & & $\begin{array}{c}\text { Less than seven years } \\
\text { Fromen years and }\end{array}$ & \\
\hline B19 & Negative & Count & $22 \%$ & $12 \%$ & $34 \%$ \\
\hline IgG & Positive & Count & $46 \%$ & $20 \%$ & $66 \%$ \\
\hline \multicolumn{2}{|c|}{ Total } & Count & $68 \%$ & $32 \%$ & $100 \%$ \\
\hline
\end{tabular}

Table.6 Seroprevalence of B19 IgM according the time post transplantation

\begin{tabular}{|c|c|c|c|c|c|}
\hline & \multicolumn{2}{|c|}{ Time passed since plantation } & \multirow[t]{2}{*}{ Total } \\
\hline & & & Less than seven years & $\begin{array}{c}\text { From seven years and } \\
\text { above }\end{array}$ & \\
\hline B19 & Negative & Count & $62 \%$ & $32 \%$ & $94 \%$ \\
\hline $\operatorname{IgM}$ & Positive & Count & $6 \%$ & $0 \%$ & $6 \%$ \\
\hline total & & Count & $32 \%$ & $68 \%$ & $100 \%$ \\
\hline
\end{tabular}

Table.7 Prevalence and hemoglobin gm\% according to (B19 IgG) test

\begin{tabular}{|c|c|c|c|c|c|}
\hline & & & \multicolumn{2}{|c|}{$\mathrm{Hb}$ gm\% } & \multirow[t]{2}{*}{ Total } \\
\hline & & & Mild & Sever & \\
\hline \multirow[t]{2}{*}{ B19 IgG } & Negative & Count & $14 \%$ & $0 \%$ & $14 \%$ \\
\hline & Positive & Count & $14 \%$ & $8 \%$ & $22 \%$ \\
\hline \multicolumn{2}{|c|}{ Total } & Count & $28 \%$ & $8 \%$ & $36 \%)$ \\
\hline
\end{tabular}


Table.8 Prevalence and hemoglobin gm\% according to (B19 IgM) test

\begin{tabular}{|c|c|c|c|c|c|}
\hline & & & \multicolumn{2}{|c|}{$\mathrm{Hb}$ gm\% } & \multirow[t]{2}{*}{ Total } \\
\hline & & & Mild & Sever & \\
\hline \multirow[t]{2}{*}{ B19 IgM } & Negative & Count & $24 \%$ & $8 \%$ & $32 \%$ \\
\hline & Positive & Count & $4 \%$ & $0 \%$ & $2 \%$ \\
\hline \multicolumn{2}{|c|}{ Total } & Count & $28 \%$ & $8 \%$ & $36 \%$ \\
\hline
\end{tabular}

Infection with parvovirus is common worldwide, affecting both sexes, and all ages with different percentages; $15 \%$ of children below 5 years old; $60 \%$ of those between age of 5 and 19 years old, up to $60 \%$ of all adult are seropositivity, and more than $90 \%$ of the elderly. About $45 \%$ of women of childbearing age do not possess protective $\operatorname{IgG}$ antibodies against B19. The incidence of acute B19 infection in pregnancy is approximately $2 \%$ in endemic periods, but in epidemic periods, the infection rate may rise to $10 \% .^{5}$

The most common manifestations of B19 infection in immunosuppressed patients are anemia and other cytopenias. Thus, this diagnosis should be considered in transplant recipients with unexplained anemia and reticulocytopenia or pancytopenia. Anemia is a common problem after renal transplantation and affects more than $40 \%$ of recipients. ${ }^{6,7}$

The prevalence of IgG Parvovirus B19 in kidney transplant in Libya and other countries in the North Africa has not been described previously. However in other country like Iraq was (18\%) Saudi Arabia (75\%), Iran $(69.2 \%)$ in this study prevalence of $\mathrm{IgG}$ was $(66 \%)$ a similar study was done in Libya in 2009 to detection B19 in pregnant women showed prevalence of $\operatorname{IgG}(61.3 \%))^{8,9,10,11}$

The prevalence of IgM in our study was $6 \%$ three samples were positive out of 50 all of the cases occur in the first years after transplantation due to high immunosuppressant. The rate was slightly higher than another study in 2009 in the same area $(5.3 \%)^{11}$, while it was $(10 \%)$ in $\operatorname{Iraq}^{8}$, Saudi Arabia (20.5\%). ${ }^{9}$ Seroprevalence of both $\mathrm{IgM}$ and $\mathrm{IgG}$ in $\mathrm{KT}$ in Libya is among the global rates of B19 prevalence.

In particular, KT recipients may acquire symptomatic PV B19 infection from the donor, from the community, or from reactivation of endogenous latent or persistent virus. Even though numerous cases of B19 infection in renal transplant patients have been reported. The clinical onus of B19 infection is not well characterized. Moreover, the association between B19 infection and anemia in KT recipients remains not fully. ${ }^{12}$ Even though $26 \%$ of positive B19 have anemia 1, our study failed to find relationship between anemia and B19 infection.

The present study concluded that the seroprevalence of B19 in Libya was common in KT. This study (as a pilot) demonstrated, in spite of small sample were used due to financial difficulty, that B19 is common among KT and may cause anemia, and other serious problems.

\section{References}

1. Amoda cororan, andsean Doyle.2004. Advances in the biology diagnosis and host pathogen interaction of parvovirus B19.J Med Microbiol. 53:459-475

2. E. Renoult, C. Bachelet, M. J. KrierCoudert, A. Diarrassouba, J. L. André, and M. Kessler, "Recurrent anemia in kidney transplant recipients with parvovirus B19 infection, 
Transplantation Proceedings, vol. 38, no. 7, pp. 2321-2323, 2006.

3. O. Egbuna, M. S. Zand, A. Arbini, M. Menegus, and J. Taylor, "A cluster of parvovirus B19 infections in renal transplant recipients: a prospective case series and review of the literature," American Journal of Transplantation, vol. 6, no. 1, pp. 225-231, 2006

4. Hani O.Ghazi, phD.2007. Prevalence of antibodies to human parvovirus B19 in childreaing age in Makkah. SSFCM. 14:1-5

5. Andrea Hemauer, AndreaGigler, RalphGarea, Albret Reichle, Hanswolf, and Susanne Modrow.1999.infection of aphesis by parvovirusB19.jurnal of general virology.80:627-630

6. Waldman M, Kopp JB. Parvovirus B19 and the kidney. Clin J Am Soc Nephrol. 2007; 2 Suppl 1: S47-56. doi: 10.2215/CJN.01060307

7. Zilinska Z, Chrastina M, Breza J, et al., Parvovirus B19 infection--the cause of severe anemia after renal transplantation. Vnitr Lek. 2010; 56(7): 774-8.

8.Hlail Z, Abdulamir A, Alsaedi A. The seroprevalence of parvovirusB19 among kidney transplant recipients Iraqi JMS. 2017; 15(1): 88-93.

9. Asim Diab. Analysis of parvovirus B19 infection in renal transplant recipient's case report. AJMR12 2013; 7(10): 909912.doi10.5897/AJMR12. 903

10. Khameneh ZR, Sepehrvand N, Sohrabi $\mathrm{V}$, et al., The seroprevalence of Parvovirus B19 among kidney transplant recipients: a single-center study. Saudi J Kidney Dis Transpl. 2014; 25(1): 16-21.

11. Elnifro E, Nisha AK, Almabsoot $M$, Daeki A, Mujber N, Muscat J. Seroprevalence of parvovirus B19 among pregnant women in Tripoli, Libya. J Infect Dev Ctries. 2009; 3: 218-20.

12. Heegaard E and Brown K (2002) Human Parvovirus B19. Clin Microbiol Rev 15: 485-505.

\section{How to cite this article:}

Musbah Almbsuot, Bayram Kiran, Elfatah Elnifro, Basm Rajab, Altayeb Elazomi, Fawzia Shawesh and Abd Alla A. Mohamed. 2019. Seroprevalance of Parvovirus B19 among Kidney Transplant in Libya. Int.J.Curr.Microbiol.App.Sci. 8(04): 998-1003. doi: https://doi.org/10.20546/ijcmas.2019.804.115 